\title{
Hydrological Problems of Fish Ponds in Urban Area of Sremska Mitrovica
}

\author{
Dragan Dolinaj, Jovan Plavša, \\ Dragoslav Pavić
}

\begin{abstract}
Today, intensive fish hatching in enclosed ponds is considered as one of the most profitable activities in Vojvodina, consequently leading to construction of large number of fish ponds in this area. Fish ponds as hydrographic objects are planned and designed at various localities. First, the localities were abandoned river meanders, then, depressions made by digging out of clay and loess, and finally, fish ponds were built intentionally for the purposes of breeding fish. The municipality of Sremska Mitrovica comprises several important hydrographic objects, among which the largest one is the Sava river, then several fresh water ponds and fish ponds. In the immediate vicinity of the town (in the north and southeast) there are two fish ponds - the fish pond "Proleće"(spring) and the fish pond owned by Nature Conservation Movement, which are both used for economic, sports and recreation, tourism, education and aesthetics purposes. This paper discusses the distribution of fish ponds, their physical and geographical features, origin and morphometric features, the regime and water quality, flora and fauna and their economic and other impacts.
\end{abstract} Key words: Sremska Mitrovica, fish ponds

Department of Geography, Tourism and Hotel Management, Faculty of Sciences, University of Novi Sad, Trg Dositeja Obradovića 3, 21000 Novi Sad, Serbia.

\section{Introduction}

Near a number of settlements in Vojvodina, there are depressions made by excavations for civil engineering purposes. In most of the cases, the catchment areas have been struck, therefore ponds or small ponds emerged (Bukurov, 1954). The two fish ponds "Proleće" and Fish pond owned by Nature Conservation Movement in Sremska Mitrovica belong to this group of ponds. Both fish ponds serve as a good practice example of turning almost insignificant hydrographic objects, made by digging soil for civil engineering purposes, or neglected objects covered with hydrophilic vegetation into artificial lakes, i.e. fish ponds of highly important economic, tourism, sports and recreation, education and aesthetic significance not only for the town of Sremska Mitrovica, but also for the whole municipality.

\section{Position and general physical and geographical features of the research area}

Sremska Mitrovica, the largest town in Srem, is situated on the left bank of the Sava river at $44^{\circ} 58^{\prime}$ latitude and $19^{\circ} 37^{\prime}$ longitude. It covers 4,961 ha and borders the areas of Veliki Radinci, Voganj, Šašinci, Jarak and Laćarak. The town's area comprises three parts. The centre is the town itself covering the area of 1,481 ha and bordering Laćarak ( $636 \mathrm{ha}$ ) in the west. It is connected by a pedestrian bridge with Mačvanska Mitrovica (174 ha) on the right bank of the Sava river. All three parts form a unique town settlement of Sremska Mitrovica, covering the total area of 2,291 ha (data obtained from the Department of Urbanism in Sremska Mitrovica).

Greater part of the town is situated on alluvial deposits, whereas the north parts of the town lay on loess. The rban area primarily covers the Pleistocene terrace, and partially the alluvial plain of the Sava river.

Sremska Mitrovica as well as the broader area of southern part of the Pannonian plain is featured by continental climate with some elements of continental and steppe climate. Mean annual air tem- perature for the town is $10.8^{\circ} \mathrm{C}$. The coldest month is January with mean temperature of $-0.9^{\circ} \mathrm{C}$, whereas the warmest month is July with mean temperature of $20.7^{\circ} \mathrm{C}$. The warmest season is summer with mean temperature of $20^{\circ} \mathrm{C}$, whereas mean winter temperature is $0.9^{\circ} \mathrm{C}$. Mean temperatures in spring and autumn are slightly different, i.e. mean spring temperature is $11.4^{\circ} \mathrm{C}$, and mean autumn temperature is $10.8^{\circ} \mathrm{C}$. To confirm the continental climate of the place, there are also the data on absolute maximum and minimum air temperatures recorded on the weather station in Sremska Mitrovica. Absolute maximum air temperature is $39.8^{\circ} \mathrm{C}$, and absolute minimum air temperature is $-29,5^{\circ} \mathrm{C}$. Mean annual precipitation in Sremska Mitrovica is $615 \mathrm{~mm}$. The highest precipitation occurs in summer $(218 \mathrm{~mm}$ on average), but the lowest precipitation occurs in winter (106 $\mathrm{mm}$ on average $)^{1}$.

In the urban area and its surroundings, shallow phreatic waters are found at depths of $2 \mathrm{~m}$ to $5 \mathrm{~m}$. Abundant artesian waters are distributed in four hydrological areas which are situated at depths from $136 \mathrm{~m}$ to $900 \mathrm{~m}$ (Plavša, 1999). Indisputably, the most significant surface hydrological object in Sremska Mitrovica is the Sava river. Apart from this water course, there are also its tributaries: Manđeloški potok, Čikas and Moharač. There are also two smaller fish ponds, the aforementioned "Proleće" and Fish pond owned by Nature Conservation Movement as integral parts of hydrographical network in the urban area of Sremska Mitrovica.

\section{Fish pond "Proleće"}

Position of the pond and its physical and geographical features. The pond is managed by the Economic Unit of the Fish pond "Proleće", within the Detention and Rehabilitation centre in Sremska Mitrovi$\mathrm{ca}$ and is situated outside the prison walls under the north wall. North of the pond there is Race course of Sremska Mitrovica.

\footnotetext{
Mean values of the observed climate elements measured at meteorological station in Sremska Mitrovica refer to the period 1981-2000.
} 
Fish pond "Proleće" is situated at the north end of the urban area of Sremska Mitrovica (appendix 1). The fish pond is situated at the distance of $3 \mathrm{~km}$ from the town centre and $600 \mathrm{~m}$ from the highway Belgrade - Zagreb (E-70). The regional road Sremska Mitrovica - Ležimir, which runs near the pond, makes the pond easily accessible. Near the regional road Sremska Mitrovica - Ležimir, i.e. $150 \mathrm{~m}$ far from the pond there is a parking connected with the pond with gravel road. The pond is, properly planned and designed, fenced as well as easily accessible.

The pond is at $75 \mathrm{~m}$ altitude. Its basin was embedded in the loess terrace, whereas the pond's bottom is made of clay layers. At several contact points of loess deposits with clay layers, phreatic aquifer which fed the pond was cut off.

Origin and morphometrics of the pond. At the beginning of 1895 , by the proclamation of Franja Josif, the construction of Detention and Rehabilitation centre in Sremska Mitrovica started. During the construction work, material was used from the vicinity, and the hole that appeared during excavations quickly filled with water due to the cut off the phreatic spring. The abandoned digging location was left unexploited for several decades. Covered in aquatic vegetation, it became the habitat of mosquitoes and waste disposal site, thus threatening the health of the local population. Several decades later, at the end of 1950s, the rejuvenation of the area for novel purposes started. The construction of the fish pond was conducted in several phases. First, the ditch in eastern part of the pond was dug, through which the water flew out of the depression. Then, the basin was cleared of aquatic vegetation, waste, and sludge deposits, and additionally widened and deepened. The last phase consisted of separating the pond basin into two parts by an embankment, and the water level regulator was built in the drainage ditch. The fish pond was drained again in 1982 for sanitation purposes. On that occasion, the entire basin of the small pond was cleared of sludge, deepened and completely covered in bricks. Also, the basin of the large pond was cleared of sludge and its was deepened significantly at certain points. The latest cleaning of the pond was performed in 1994, but only partially in the large pond sections.

Fish pond "Proleće" stretches on the west-east axis. The small pond is situated west of the large pond and its is a square in shape. The larger pond is in the east and its shape is elongated, wider in its western part, whereas its width decreases in its eastern part. The sides of the pond's basin are vertical, the shore being higher than the middle level of the pond for 80

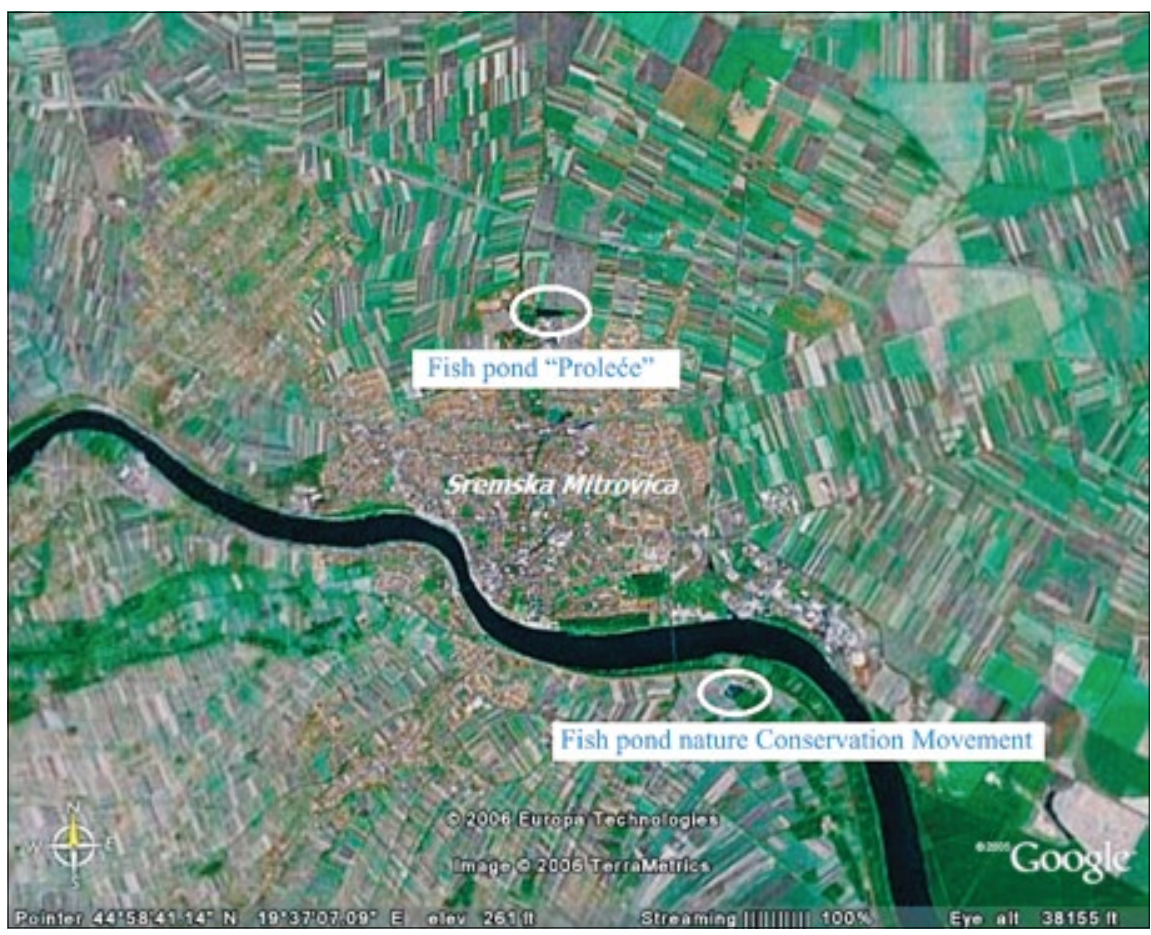

Appendix 1 Satellite picture of geographical position of Fish pond "Proleće" and Fish pond of nature Conservation Movement (Source: Google Earth)

$\mathrm{cm}$. The shore at all sides of both the small and the large pond is flat without observable steeps.

Smaller pond is $39 \mathrm{~m}$ long on the southwestern to north-eastern axis, a maximum width of $34 \mathrm{~m}$ determined in the north western and south-eastern direction. The average width of the smaller pond is 19.6 $\mathrm{m}$. The length of the shore line at the smaller pond is $111 \mathrm{~m}$. The shape of the basin is almost of regular shape and its depth increases gradually and laterally towards the central part. The maximum depth determined in the central part is $2.20 \mathrm{~m}$, whereas the average depth of the smaller pond is $1.2 \mathrm{~m}$. The surface of the smaller pond

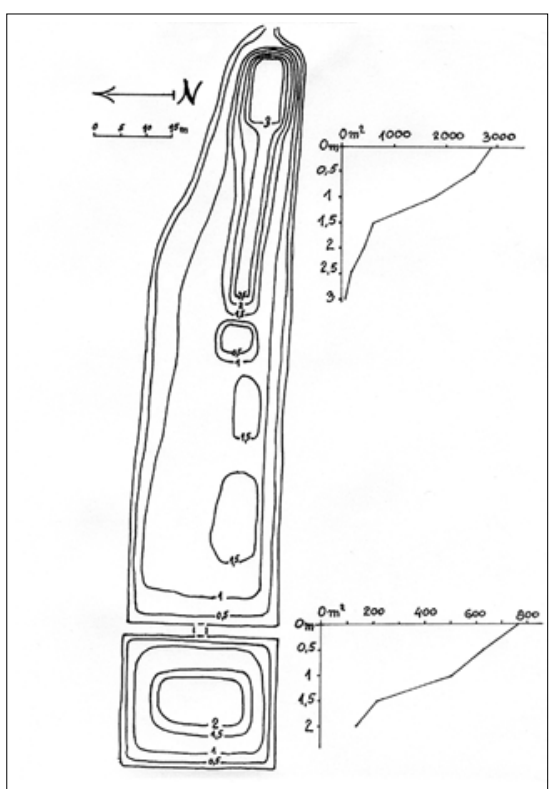

Map 1 Isobathic map of Fish pond "Proleće" with bathigraphic curves of the large and small pond covers $756 \mathrm{~m}^{2}$. Due to the vertical sides of the pond there are minimal water level oscillations and the surface area remains the identical throughout the year. The small surface and shallow water depth contribute to smaller quantity of water which is on average $900 \mathrm{~m}^{3}$.

The larger pond is $119 \mathrm{~m}$ long on the north-west to south-east axis. On the north-east to south-west axis a maximum width of the pond it $30 \mathrm{~m}$, whereas the average estimated width is $24.3 \mathrm{~m}$. The length of its shoreline is $268 \mathrm{~m}$. The basin of the larger pond is elongated on the west-east axis, the west section being considerably wider with gradual decrease of the width towards the east. On the contrary to the smaller pond, the larger pond basin has not been thoroughly planned and designed. This caused huge discrepancies in depths between eastern and western sections of the pond basin. The west part is shallower, whereas major portion of the pond floor is between $1 \mathrm{~m}$ and $1.5 \mathrm{~m}$ isobaths. The deepest water depth estimated in the area of two smaller depressions is $1.7 \mathrm{~m}$. There are large discrepancies in water depths in the east section of the pond. At the meeting point of the west and the east sections there is an elevation with the flat top only $0.4 \mathrm{~m}$ beneath the water surface. Towards the east, the depth in the pond abruptly increases to $2.5 \mathrm{~m}$, and towards the furthest eastern section it reaches the value of 3.1 $\mathrm{m}$. The steepest side of the basin is in the southeastern section, where the isobaths are closely-spaced. The depth of $3 \mathrm{~m}$ is recorded at $5.5 \mathrm{~m}$ distance from the shore, and the side slope gradually decreases towards the floor. The deeper section of the 
pond is situated in its middle eastern section, elongated on the west-east axis, with depth values between $2 \mathrm{~m}$ and $3 \mathrm{~m}$. The average depth of the large pond is $1.1 \mathrm{~m}$. The surface area remains unchanged throughout the year with its value of $2,888 \mathrm{~m}^{2}$. The capacity of the pond basin is $3,250 \mathrm{~m}^{3}$.

The pond water level regime. Between the two ponds there is a hydrological bond by a canal, which is $2.5 \mathrm{~m}$ wide and approximately $3 \mathrm{~m}$ long. The water inflow to both pond's basins occurs in several ways, at the surface level, by groundwater inflow and recharging the pond aquifer by precipitation.

The most important component of water inflow process is groundwater inflow. On the loess terrace in the north part of Sremska Mitrovica, phreatic aquifer lies at depth of $2.5 \mathrm{~m}$ to $4 \mathrm{~m}$. The decrease of topographic area on the north-south axis is accompanied by phreatic spring, but the aquifer which recharge the ponds, and collect precipitation in the wide area north of the fish pond and Sremska Mitrovica.

During the planning and adaptation of the pond in 1982, the pond was drained. The presence of groundwater springs and their precise location was recorded. In the small pond basin, at the $7 \mathrm{~m}$ distance from the north shore and $10 \mathrm{~m}$ from the east shore, a spring at the depth of $2 \mathrm{~m}$ was found, with water flow frequency estimated to $20 \mathrm{l} / \mathrm{min}$. Within the large pond basin, the presence of two springs was recorded. Both were situated in two separate minor depressions in the west section of the large pond basin closer to the south shore. The first spring was found in deeper depression at $1.5 \mathrm{~m}$. Its distance from the west shore is $15 \mathrm{~m}$, and from the south $13 \mathrm{~m}$. In the east from this spring, there is a smaller depression with a spring at $1.5 \mathrm{~m}$ of depth, which is $37 \mathrm{~m}$ far from the west shore and $9 \mathrm{~m}$ far from the south shore. Since both springs were found in smaller depression, during the drainage process of the larger pond, they both kept water therefore the water flow measurements were less precise. Both springs have approximate water flow between 25 to $30 \mathrm{l} / \mathrm{m}$.

Wider zone of the pond encompasses flatted area with permeable sediments on the surface. In such situations, precipitation flows off the surface slowly, the excess which has not evaporated or been utilized by plants, infiltrates into a phreatic well, and the pond is directly being fed by precipitation on the aquatoria size of the pond.

Apart from these forms of recharging, the smaller pond is also surface-fed. In the second half of the 1980s, within the prison in Sremska Mitrovica researches were conducted on the second hydro-arthesian area which stretches in the area of Srem-
Table 1 Mean water temperatures $\left({ }^{\circ} \mathrm{C}\right)$ in Fish pond "Proleće" for January, April, July and October in the period 2003-2006

\begin{tabular}{|c|c|c|c|c|}
\hline January & April & July & October & mean annual \\
\hline 0.8 & 10.6 & 25.5 & 13.9 & 12.7 \\
\hline
\end{tabular}

ska Mitrovica at depths between $252 \mathrm{~m}$ and $311 \mathrm{~m}$. An artesian well was drilled in order to estimate the precise depth of the water layer, its potentials and water quality. Upon the completion of the research, the well was not closed, but the water was directed to flow freely into the smaller fish pond. Consequently, the pond received additional $30 \mathrm{l} / \mathrm{m}$.

The water levels of both the small and the large pond are maintained by a barrier with a vent positioned at the outgoing ditch at the furthest eastern part of the large pond. Furthermore, the water loss from the ponds occurs through evaporation and water loss through ground. The water from the small pond flows towards the large pond, and then from the large towards the southeast, i.e. in the direction south of the drainage canal.

Water features and flora and fauna of the pond. Measures of water temperature were conducted at regular intervals in 2003 2004,2005 and 2006 in January, April, July, and October. The measurements were conducted three times a day, every sixth day in one month. Besides these, occasional water temperature measurements were conducted in other months.

The highest recorded air temperatures were in July and August, when mean daily water temperatures exceed $25^{\circ} \mathrm{C}$. In autumn, water temperature is on average for about $3^{\circ} \mathrm{C}$ higher than in spring. In January and February, water temperature at the pond is the lowest and fluctuates be- tween $0.6^{\circ} \mathrm{C}$ and $0.9^{\circ} \mathrm{C}$. During winter, the ice on the pond surface is regular phenomenon. In 2003 the pond was covered with ice for 18 days, in 2004 for 21 days, in 2005 for 29 days and in 2006 for 27 days.

The water in both the small and the large pond is not very transparent. The ponds are almost completely covered in aquatic vegetation. The east section of the larger pond is covered with reed, whereas the other sections of the large and the small pond are covered with aquatic vegetation. Aquatic vegetation covers approximately $95 \%$ of the pond surface in the large pond and approximately $90 \%$ in the small pond.

Institute of health protection in Sremska Mitrovica took water samples in the fish pond "Proleće" on $27^{\text {th }}$ July 2003, on the basis of which further analyses were conducted in order to estimate its quality, as well as its basic physical and chemical features.

The biggest problem of the pond is huge organic production and presence of thick sludge deposits on the pond floor. In the central part of the small pond, the thickness of the sludge deposit layer is between $80 \mathrm{~cm}$ and $90 \mathrm{~cm}$. At both sides of the basin the layers are about $60 \mathrm{~cm}$, whereas the bottom layers reach between $70 \mathrm{~cm}$ and $90 \mathrm{~cm}$.

Ichtio fauna of the pond is rather rich. There are high quality fish species such as common carp, tench and pike. The stock of white fish is also important: silver crucian carp, roach, perch and rudd. Apart from these species, there is also grass carp as fish intended for commerce. Unfortunate-

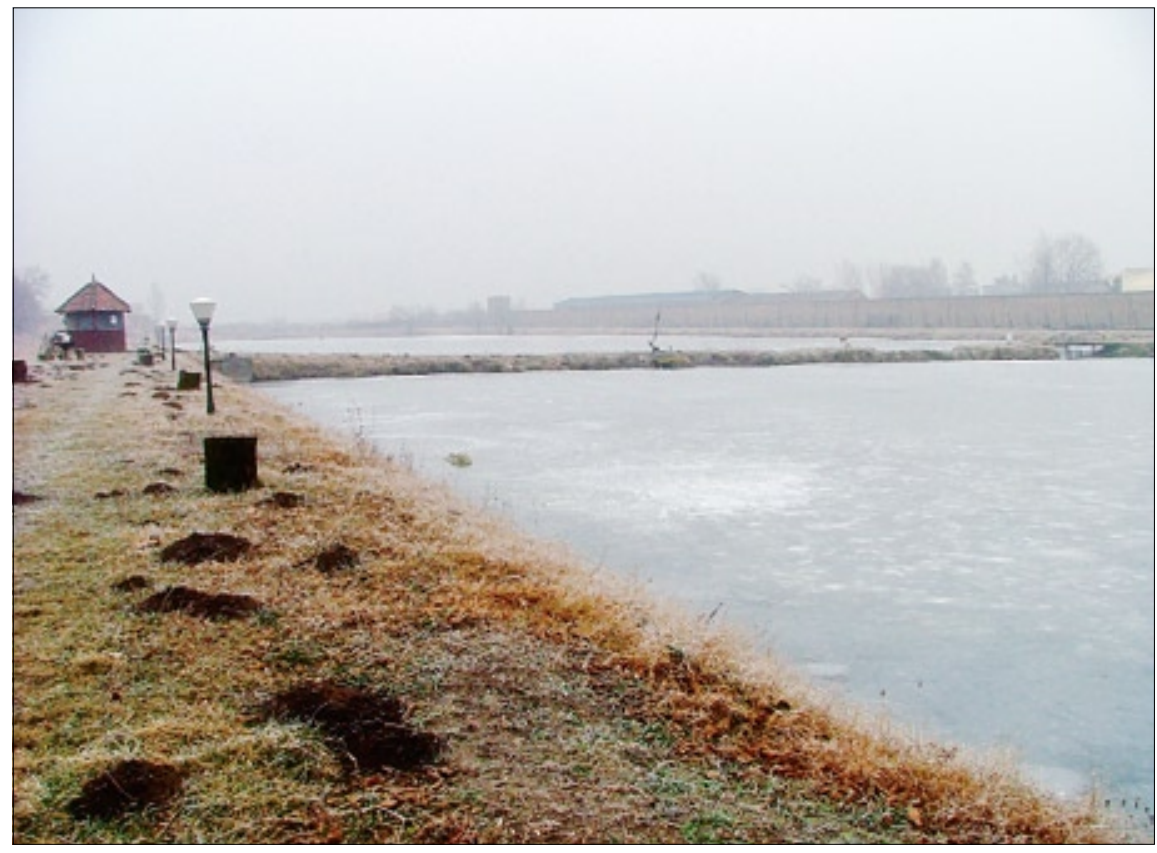

Picture 1 Fish pond "Proleće" covered with ice 
ly, there are alochtonous fish species such as American catfish and which cause a lot of damage to the fish pond.

Importance of the pond. At the ponds of the Economic Unit of the Fish pond "Proleće" the farming of highest quality fish species has been performed. In the late 1990 , the decision was reached to change the main purpose of the pond due to unprofitable farming. The shorelines of the ponds were designed and economic fish harvesting reduced. In the next years the fish stock was improved and conditions were met for introducing new purpose to the ponds, i.e. sports and fishing. Economic harvesting is still present, but significantly reduced, with strict control of the amount of the harvesting in order not to endanger sports and fishing potentials of the pond.

Outstanding quality of fish stock, variety of fish species and well-designed site are the main attributes of the pond. Vicinity of the urban area and traffic lines, makes this place easily accessible to all those interested in sports fishing.

\section{Fish pond of Nature Conservation Movement Sremska Mitrovica}

Position of the pond and its physical and geographical features. In the vicinity of the town of Sremska Mitrovica, $1.5 \mathrm{~km}$ southeast from the centre there is a Fish pond of Nature Conservation Movement Sremska Mitrovica (appendix 1). The easiest access to the pond is from north direction, from regional road Sremska Mitrovi$\mathrm{ca}$ - Bogatić, after crossing the bridge over the Sava river, there is a country trail driving to the east. 6oom away there is a parking near the pond. This is the only access to the pond which is being maintained throughout the year.

The pond is also accessed by country trails between arable lands from different directions. As a rule, those trails are of low quality due to the fact that they are being used as the only access to arable land by agricultural machines. The pond is well organized and completely fenced, and there is also a huge car parking next to it.

The pond basin is dug into the alluvial plain of the Sava river. The sides of the basin are made of the river deposits of different size diameters with horizontal layers. The bottom of the pond is formed of clay layers. In the process of cleaning and planning the pond basin, several points of phreatic springs were found, which feed the pond with water. Most of the springs are found between the river deposits and clay layers.

Origin and morphometrics of the pond. The largest and the most important hydrological object is the Sava river in the
Table 2 Results of water quality analysis in Fish pond "Proleće"

\begin{tabular}{|c|c|c|c|}
\hline № & Parametre & Unit of measure & Established value \\
\hline 1 & Water temperature & ${ }^{\circ} \mathrm{C}$ & 25 \\
\hline 2 & colour & & hardly visible \\
\hline 3 & smell & & smell of sludge \\
\hline 4 & Waste deposits & & Yes, brown particles \\
\hline 5 & $\mathrm{PH}$ value & & 8 \\
\hline 6 & Turbidity & NTU & 8.07 \\
\hline 7 & Electro conductibility & Micro S/cm & 487 \\
\hline 8 & Dry residue of filtrated water & $\mathrm{mg} / \mathrm{l}$ & 248 \\
\hline 9 & Suspended mat. & $\mathrm{mg} / \mathrm{l}$ & 88 \\
\hline 10 & Dissolved oxygen & $\mathrm{mg} / \mathrm{l}$ & 3,5 \\
\hline 11 & Saturation & $\%$ & 62.9 \\
\hline 12 & $\mathrm{BPK}_{5}$ & $\mathrm{mgO}_{2} / \mathrm{l}$ & 5.7 \\
\hline 13 & Use of $\mathrm{KmnO}_{4}$ & $\mathrm{mg} / \mathrm{l}$ & 7.5 \\
\hline 14 & HPK & $\mathrm{mgO}_{2} / \mathrm{l}$ & 9 \\
\hline 15 & TOC & $\mathrm{mg} / \mathrm{l}$ & 2.75 \\
\hline 16 & Ammonium $\left(\mathrm{NH}_{3}\right)$ & $\mathrm{mg} / \mathrm{l}$ & $<0.05$ \\
\hline 17 & Nitrites (as N) & $\mathrm{mg} / \mathrm{l}$ & 0.11 \\
\hline 18 & Nitrates (as N) & $\mathrm{mg} / \mathrm{l}$ & 0.36 \\
\hline 19 & Alkylbenzenesulphonate & $\mathrm{mg} / \mathrm{l}$ & $<0.5$ \\
\hline 20 & Iron & $\mathrm{mg} / \mathrm{l}$ & 0.0 \\
\hline 21 & Manganese & $\mathrm{mg} / \mathrm{l}$ & $<0.01$ \\
\hline
\end{tabular}

Source: Institute of health protection in Sremska Mitrovica municipality of Sremska Mitrovica. The highest mean water level on the Sava river near Sremska Mitrovica occurs in April. Following the April maximum value, the high water level is recorded in March, May and February. The lowest mean water level of the Sava river near Sremska Mitrovica increases from August to December, then a slight decrease is recorded in January, and again from January to April it increases. The water level on the Sava river near Sremska Mitrovica decreases from April until August. The highest increase in mean water level near Sremska Mitrovica is recorded in October and November, but the most prominent decrease is recorded in June and July (Dolinaj, 2005). Absolutely the highest water level on the Sava river near Sremska Mitrovica was recorded on 26th October 1974 and it was $799 \mathrm{~cm}$. High values of water level were also recorded on the following dates: $21^{\text {st }}$ April 1931 (758 $\mathrm{cm})$, on $22^{\text {nd }}$ November $1940(761 \mathrm{~cm})$, on $12^{\text {th }}$ December $1944(768 \mathrm{~cm})$ and $4^{\text {th }}$ April $1962(780 \mathrm{~cm})$. In those years, there were extensive floods causing a lot of damage in the area of Sremska Mitrovica. In the mid 1970s, the groundwork for construction of

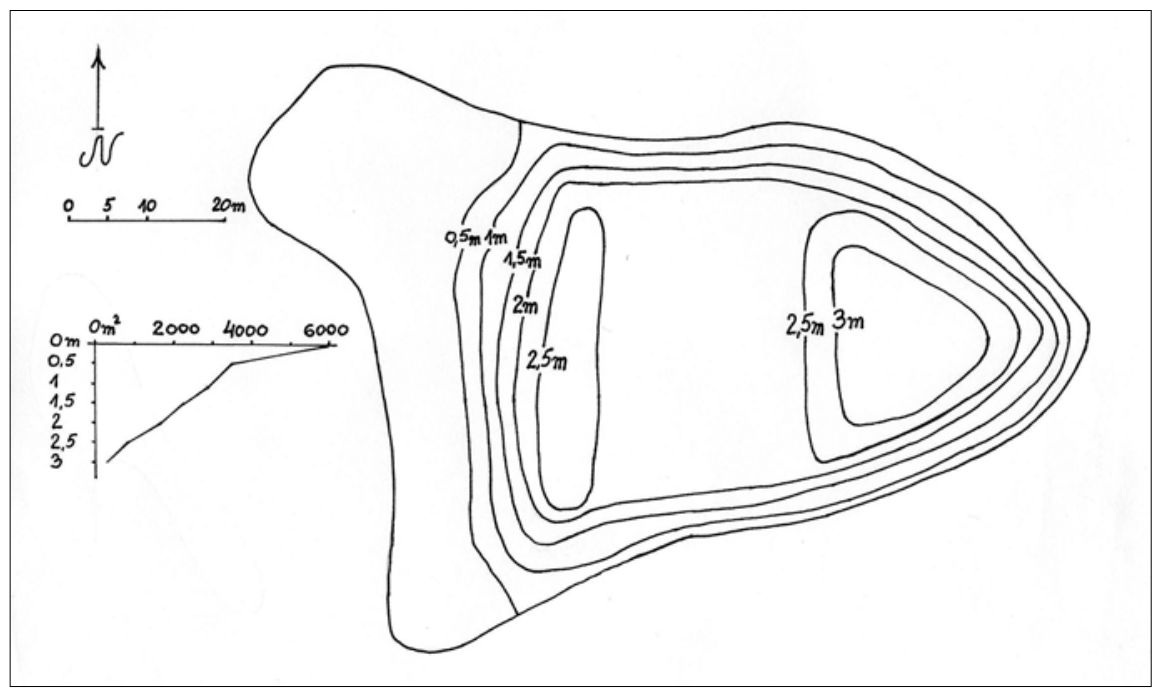

Map 2. Isobathic map of Fish pond of Nature Conservation Movement with bathigraphic curves of the large and small pond 


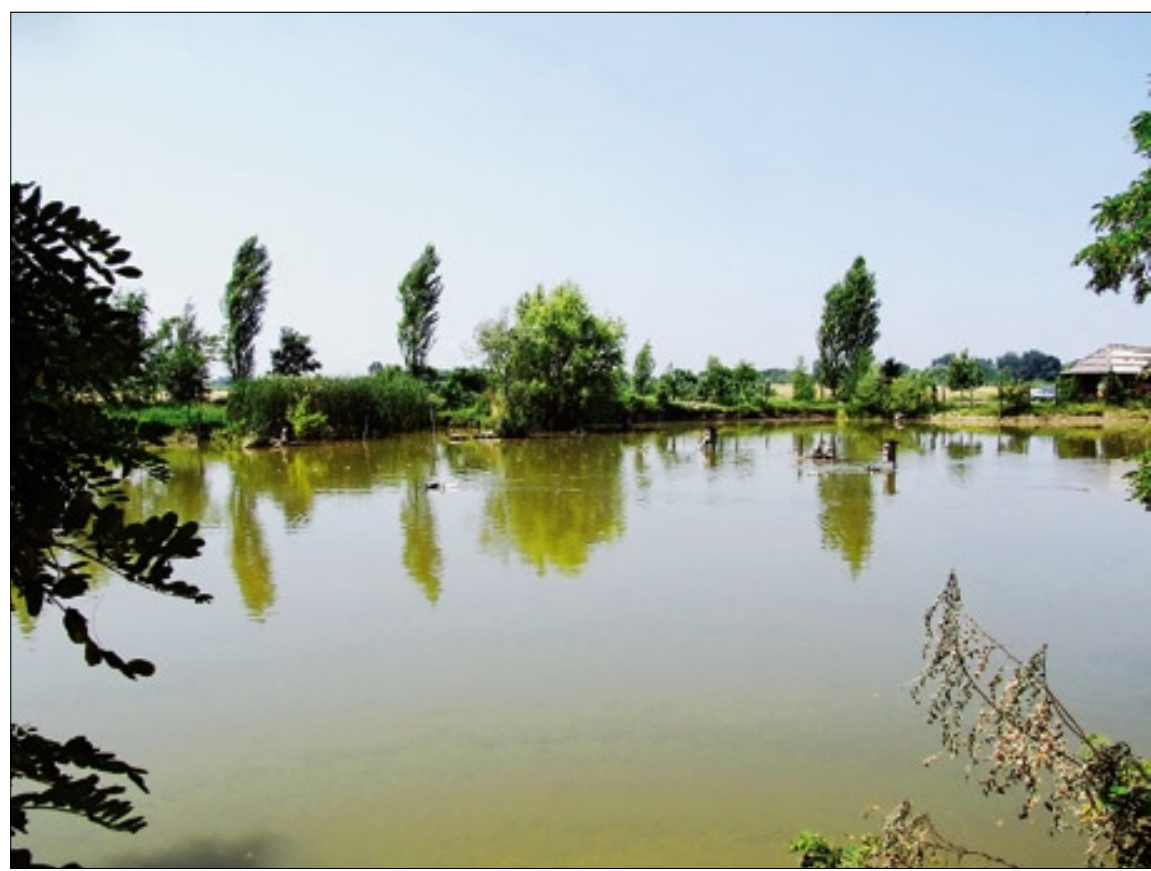

Picture 2 Fish pond of Nature Conservation Movement - Sremska Mitrovica

the embankment along the Sava river bed started. The building of the embankment lasted for over ten years and it was finally completed in 1986. Basically, the embankment was covered in concrete plates and reinforced by crushed rocks in the river bed. The part of the embankment outside the town remained without concrete plates. The building of the embankment demanded huge amounts of ground. At several localities along the Sava river in the wider area of the alluvial plain severe digging was performed for the construction purposes. One of the companies involved in building was Hidrograđevinar from Sremska Mitrovica, which performed digging works at several localities. One of those localities was the present Fish pond of $\mathrm{Na}$ ture Conservation Movement.

The pond is irregularly shaped and slightly elongated on the east-west axis. The pond is wider in the west part, whereas its width lessens towards the east. The sides of the pond's basin are vertical, and of higher altitude than the basin for about 50-80m. The shore at all sides is flat without steeps and covered in grass, trees and plants.

The pond is $110 \mathrm{~m}$ long on the north-west to south-east axis. In the west part, vertical to the length the largest width of $70 \mathrm{~m}$ is measured. Average width of the pond is $54.8 \mathrm{~m}$. The length of the shore line changes during the year and its values is approximately $300 \mathrm{~m}$. The basin of the pond is of uneven depth. The west part is the shallowest. By the west shore, there is a wide plateau with depths of $0.5 \mathrm{~m}$. From this plateau towards the east, the depths increase gradually. Conversely, on the other sides the depths abruptly increase from the shore towards the middle part of the pond. In the middle part of the pond there is a central plateau with depths between $2 \mathrm{~m}$ and $2.5 \mathrm{~m}$.
This central plateau also comprises two depressions. The west depression is shallower, slightly deeper than $2.5 \mathrm{~m}$ and elongated in the north-south direction. Eastern depression is of irregular shape, almost triangular and deeper, with the deepest point of 3.1 $\mathrm{m}$. Average depth of the pond is $1.2 \mathrm{~m}$. The surface area of the pond is $6,030 \mathrm{~m}^{2}$ and it remains unchanged throughout the year. The capacity of the pond basin is $7,130 \mathrm{~m}^{3}$.

The pond water level regime. During the excavations for the embankment construction, it was recorded that in this area the first phreatic aquifer was rather shallow at the average depth between 2 and 2.5 $\mathrm{m}$. Even though, the machines dug the soil up to a maximum depth of $2 \mathrm{~m}$, the water filled a part of the basin during periods of high phreatic aquifer level.

This basin was forgotten and neglected for years until the management was offered to the Nature Conservation Movement Sremska Mitrovica. Soon afterwards, the sanitation and restoration of the basin were performed. Furthermore, the basin was deepened at certain points. During the restoration process, it was discovered that the pond was spring-fed by several springs. According to estimations, the pond receives between $15 \mathrm{l} / \mathrm{min}$ and $110 \mathrm{l} / \mathrm{min}$ on average during a year. The amount of received water depends on the season and the level of phreatic aquifer.

The output of water occurs in several ways. The excess water overflows from the pond into the canal, dug east of the pond

Table 3 Mean water temperatures $\left({ }^{\circ} \mathrm{C}\right)$ in Fish pond of Nature Conservation Movement Sremska Mitrovica for January, April, July and October in the period 2003-2006

\begin{tabular}{|c|c|c|c|c|}
\hline January & April & July & October & mean annual \\
\hline 0.2 & 9.8 & 26.5 & 11 & 11.8 \\
\hline
\end{tabular}
$0^{\circ} \mathrm{C}$ and $0.4^{\circ} \mathrm{C}$. During winter, the ice on the pond surface is a common phenomenon. In 2003 the pond was covered with ice for 36 days, in 2004 for 41 days, 2005 for 40 days and in 2006 for 37 days.

The water is not very transparent throughout the year, probably due to high biological production and algae presence. The ponds is significantly covered in vegetation. The east section of the pond is almost completely covered with reed and aquatic vegetation, whereas the other sections are partly covered with aquatic vegetation.

Neither water quality analysis nor physical water properties were conducted.

The largest problem of the pond is huge organic production and presence of thick sludge layers at the bottom of the pond. In the east section of the pond, sludge layers are approximately $50 \mathrm{~cm}$ thick.

Ichtio fauna of the pond is versatile. In relation to quality fish species, the pond is the habitat of catfish, common carp, tench and pike. White fish stock is also significant: gold crucian carp, roach, perch and rudd. Alochtonous species are not found in the pond.

Importance of the pond. Upon the completion of the building of the embankment in mid 1980s, this basin was neglected and forgot. The basin rapidly declined, covered in thick swamp vegetation and water plants it became the habitat of mosquitoes. In early 1990s, the Nature Conservation Movement - Sremska Mitrovica demanded and was granted the manage-

pond of Nature Conservation Movement

to carry the water to the bed of the Sava river in the periods of high level of phreatic waters. Smaller amounts of water are lost through direct evaporation from the surface of the pond. The level of the pond is maintained and it remains unchangeable throughout the year.

Water features and flora and fauna of the pond. Measures of water temperature were conducted at regular intervals in 2003. 2004,2005 and 2006 in January, April, July, and October. The measurements were conducted three times a day, every sixth day in one month. Besides these, occasional water temperature measurements were conducted in other months.

The highest recorded air temperatures were in July and August, when mean daily water temperatures exceed $26^{\circ} \mathrm{C}$. In autumn, water temperature is on average for about $1.5^{\circ} \mathrm{C}$ higher than in spring. In January and February, water temperature at the pond is the lowest and fluctuates between 
ment upon this basin with the obligation of cleaning, designating and using it for economic or educational purposes. Due to the enormous efforts and strivings of its members, financial aid of numerous companies and the municipality of Sremska Mitrovica itself, the basin was cleaned, the pond deepened and completely filled with water. The reconstruction work has not been completed yet, but there are plans on widening and deepening the shallower western and southern sections of the basin which would significantly increase its surface area and volume.

Today, the pond is still managed by the Nature Conservation Movement - Sremska Mitrovica and it is being used as a fish pond in order to fund its maintenance. Apart from this function, there are also sports and fishing performed at the pond. A large number of fishing fans regularly visits this pond which offers facilities for their pleasant stay. Moreover, there is something that might be among the most important of all purposes of the pond. A lot of children visit the pond every year, most of them staying in camps organized by the Nature Conservation Movement. Near the pond, Nature Conservation Movement owns accommodation facilities which provide several day stays for smaller groups of children. During their stay, the children are taught about flora and fauna of the pond, the Sava river area, and Special Nature Reserve Zasavica, which is situated in the vicinity. This educational role of the pond is certainly its most important among its functions.

\section{Conclusion}

Near a large number of settlements in Vojvodina, depressions appeared after ex- cavations for civil engineering purposes. In most of the cases, the catchment areas have been struck, therefore ponds or small ponds emerged. The two fish ponds belong to this group of ponds.

The fish pond "Proleće" emerged in the depression which was formed due to excavations works during the construction of the prison. Later, the depression was deepened and converted into a fish pond. The fish pond changed its purpose in 1990s. The prison management reached the decision to switch its utilization to sports and fishing tourism purposes. The pond has been revitalized, the water quality is constantly being controlled. Moreover, the former fish stock which used to form the basis for economic hatching has been increased several times and found its place in the tourist offer of the pond. The problems of aquatic vegetation should be solved within the next years, by introducing grass carp, and by a planned sludge deposits removal from one sector of the pond. Fish protection service has been active, and the pond access has been improved. The results of these activities are observable, not only is the pond being visited throughout the year, but also the fishers and nature lovers ask for more accommodation facilities. The fish pond "Proleće" in Sremska Mitrovica is an example of financial sustainability of the pond with its primary purpose of sports and fishing.

Guided by this example, Natural Conservation Movement of the municipality of Sremska Mitrovica reached the decision to revitalize the bogs which emerged during the construction of the embankment south of the Sava river and adjust them for tourism purposes. The construction works on the basin have been conducted for several years. The surrounding area has been forested, and the quality fish species attractive for sports fishing have been introduced to the pond. In the vicinity of the pond, the mini zoo has been opened for visitors to see certain autochthonous domestic species. The pond is visited by a number of young people every year.

Tourist offer of Sremska Mitrovica has been formed on the basis of cultural and historical heritage, archaeological sites, remains of the antique Sirmium, as well as natural values of Special Nature Reserve Zasavica. Tourist launching of small ponds in the urban area of Sremska Mitrovica may add extra value to its tourist offer by making it more attractive and contributing to its variety.

\section{References}

Bukurov, B. 1954. Jezera i bare u Bačkoj, Zbornik Matice srpske za prirodne nauke 5, 51-60

Dolinaj, D. 2005. Geografske osnove nautičkog turizma na reci Savi u Srbiji, Magistarska teza, Geografski fakultet, Beograd.

Dolinaj, D. 2006. Jezera u gradskoj zoni Sremske Mitrovice, Globus 31, 123-132

Plavša, J. 1999. Sava. Vode Srema, Institut za geografiju, Noovi Sad: 41-70

Ristanović, B., Dolinaj, D. 2006. Ribnjak „Proleće” u Sremskoj Mitrovici. Zbornik radova Departmana za geografiju, turizam $i$ hotelijerstvo 35, 26-32

Generalni urbanistički plan za Sremsku Mitrovicu do 2010. godine, Sremska Mitrovica, 200o.

Klimatološki godišnjaci, Republički hidrometeorološki zavod, Beograd, 19812000. 